\title{
Documenting trumpet leaf-miner moths (Tischeriidae): new Neotropical Coptotriche and Astrotischeria species, with notes on Sapindaceae as a host-plant family
}

\author{
JONAS R. STONIS ${ }^{1 *}$, ARŪNAS DIŠKUS ${ }^{1,5}$, ANDRIUS REMEIKIS ${ }^{1,6}$, JOSÉ L. FERNÁNDEZ-ALONSO ${ }^{2,7}$, \\ SVETLANA V. BARYSHNIKOVA ${ }^{3,8} \&$ M. ALMA SOLIS ${ }^{4,9}$ \\ ${ }^{I}$ Nature Research Centre and Baltic-American Biotaxonomy Institute, Akademijos St. 2, Vilnius 08412, Lithuania. \\ ${ }^{2}$ Real Jardín Botánico - CSIC, Claudio Moyano 1, Madrid 28014, Spain. \\ ${ }^{3}$ Zoological Institute, Russian Academy of Sciences, Universitetskaya nab. 1, St. Petersburg, Russia. \\ ${ }^{4}$ Systematic Entomology Laboratory, ARS, US Department of Agriculture, National Museum of Natural History, Smithsonian Institu- \\ tion, Washington, D.C., 20013-7012, USA. \\ 5 "Ddiskus.biotaxonomy@gmail.com; ○ https://orcid.org/0000-0003-0106-5546 \\ ${ }^{6}$ ”" remeikis.andrew@gmail.com; (1) https://orcid.org/0000-0002-9310-1112 \\ 7 ”-jlfernandeza@rjb.csic.es; $\odot$ https://orcid.org/0000-0002-1701-480X \\ 8!" parornix@zin.ru; @ https://orcid.org/0000-0002-2549-4911 \\ 9 ["alma.solis@usda.gov; ㄴ https://orcid.org/0000-0001-6379-1004 \\ ${ }^{*}$ Corresponding author. "stonis.biotaxonomy@gmail.com; 내ttps://orcid.org/0000-0002-8411-3162
}

\begin{abstract}
Four new species of trumpet leaf-miner moths (Tischeriidae) are described from the Neotropics: Coptotriche serjaniphaga Remeikis \& Stonis, sp. nov., feeding on Serjania Mill. (Sapindaceae), Astrotischeria mystica Diškus \& Stonis, sp. nov., feeding on Verbesina L. (Asteraceae), A. yungasi Diškus \& Stonis, sp. nov., feeding on Oyedaea DC. (Asteraceae), and $A$. parapallens Diškus \& Stonis, sp. nov., feeding on Baccharis L. (Asteraceae). Records on Sapindaceae-feeding Tischeriidae are very rare and Serjania is a novel host-plant genus for Tischeriidae. It is hypothesized that Serjania, a diverse genus in the tropical and subtropical Americas, may be a host for many undiscovered species of specialized stenophagous Tischeriidae. The new species are illustrated with photographs of the adults, male and, if available, female genitalia, and the leaf mines. We briefly discuss the importance of new species descriptions as a part of biodiversity assessment.
\end{abstract}

Key words: Andean Asteraceae, leaf mines, Serjania, taxonomy, trumpet leaf-miner moths

\section{Introduction}

Leaf-mining lepidopteran families, including the Tischeriidae, known as trumpet moths or trumpet leaf-miner moths, are characterized by a highly specialized, stenophagous lifestyle, i. e. feeding on a limited range of host plants and mining the photosynthetic tissues of leaves or other plant organs. They also represent distinct moth families with uniquely modified morphological characters. The specialized characters of Tischeriidae were extensively reviewed by Braun (1972) and Puplesis \& Diškus (2003), as well as analysed and illustrated in many recent publications, notably by Diškus \& Stonis (2012, 2015), Xu et al. (2017, 2018), Stonis et al. (2017, 2018, 2019a, 2020a, 2020b, 2020c, 2021), and Stonis \& Solis (2020).

The study of the tischeriid fauna in the Neotropics began in the late nineteenth to early twentieth century with descriptions of some new species from the Caribbean, southwestern Mexico and South American countries (a review of geographical distribution and species description was provided by Stonis et al. 2019b). Stonis et al. (2019b) also hypothesized that Tischeriidae might represent a significant portion of the Neotropical fauna of leaf-mining insects, and in support of this, we continue to discover new species of trumpet moths in the Neotropics. In this study, we describe new species of Tischeriidae from the Central Andes in order to have their names and host-plant data 
available for our on-going molecular analysis of the family and to introduce Serjania Mill. as a novel host-plant genus for Tischeriidae. We discuss the importance of new species descriptions and recent developments as a part of biodiversity assessment.

\section{Materials and methods}

The descriptions of the new species are based on material deposited at the Zoological Institute of the Russian Academy of Sciences, St. Petersburg (ZIN); some paratype specimens were also deposited at the Nature Research Centre, Vilnius, Lithuania (NRC).

Protocols regarding the study of Tischeriidae have been previously described: collecting and rearing of leaf mines by Stonis et al. (2018), and techniques of specimen dissection and genitalia mounts in Euparal by Stonis et al . (2014). The descriptive terminology, with a few exceptions, follows Puplesis \& Diškus (2003).

Permanent preparations on microscope slides were photographed and studied with a Leica DM2500 microscope and Leica DFC420 digital camera. Adults were measured and studied using Lomo stereoscopic microscopes MBS10 and photographed using a Leica S6D stereoscopic microscope with attached a Leica DFC290 digital camera. Figure 16 was photographed using a Lomo MBS10 stereoscopic microscope and a temporarily attached cellular telephone Samsung Galaxy S7 with a camera.

For molecular analysis, genomic DNA was extracted from hindlegs stored in $96 \%$ ethanol, using the GeneJet Genomic DNA Purification kit (Thermo Fisher Scientific Baltics) according to the manufacturer's specifications. Sequencing was produced by the BigDye ${ }^{\circledR}$ Terminator v3.1 Cycle Sequencing Kit (Applied Biosystems) in Macrogen Inc. (Seoul, South Korea).

For host-plant identifications we used photographic images of the host plants taken in the field and specialized literature about regional floras; herbarium specimens were not collected and therefore not available for identification purposes. Type specimen images of identified plants and related plant species were reviewed using JSTOR-Global Plants (https://plants.jstor.org) and Tropicos.org (http://www.tropicos.org), as well as herbarium sheets deposited mainly in the following herbaria: COL, CUZ, F, K, M, MA, MO, P, QCA, and US (acronyms follow Thiers 2021).

\section{Taxonomic account}

Coptotriche serjaniphaga Remeikis \& Stonis, sp. nov. urn:lsid:zoobank.org:act:71EE7F8A-D544-41E7-829E-1D75743783E2

(Figs. 11-18)

Type material. Holotype: ${ }^{\lambda}$, PERÚ, Dept. Apurímac, Curahuasi, $13^{\circ} 32^{\prime} 02^{\prime \prime} \mathrm{S}, 72^{\circ} 42^{\prime} 59^{\prime \prime} \mathrm{W}$, ca. $2700 \mathrm{~m}$, mining larva 25.v.2018, leg. Arotaype-Puma (NRC).

Diagnosis. Externally, this new species is similar to the Peruvian C. carmencita Stonis \& Diškus described and illustrated in Stonis et al. 2019a: figs. 23, 24, 57-62, 115-120). However, C. serjaniphaga sp. nov. is a significantly larger moth, $9 \mathrm{~mm}$ in wingspan (C. carmencita, 5.6-5.8 mm). Coptotriche serjaniphaga $\mathbf{s p . ~ n o v . ~ d i f f e r s ~ i n ~ t h e ~ d a r k ~}$ golden ochre forewing, thorax, and frontal tuft (C. carmencita is a pale, entirely ochreous yellowish moth). In $C$. serjaniphaga, dark scales form two small, irregular, subapical spots; the tornal spot (Fig. 15) is distinctive (in $C$. carmencita, forewing is irregularly speckled with dark scales which are especially abundant along the tornal margin of forewing).

The host-plant genus Serjania Mill. (possibly S. squarrosa Radlk.) is distinctive (see Discussion). Additionally, C. serjaniphaga sp. nov. has been discovered in temperate areas of the Peruvian Andes and C. carmencita occurs in the subtropical, humid habitats of the Peruvian "selva alta" which seems to be a transitional corridor between the montane regions and tropical lowlands, or the Amazonian selva or "selva baja".

Male (Figs. 14, 15). Forewing length $4.25 \mathrm{~mm}$; wingspan $9.0 \mathrm{~mm}(\mathrm{n}=1)$.

Head. Frons yellowish ochre; palpi golden cream; pecten brownish cream; frontal tuft glossy golden cream, laterally golden ochre; collar golden ochre; antenna distinctly longer than one half the length of forewing; flagellum pale grey, golden glossy, with relatively short, very fine, inconspicuous sensilla. 

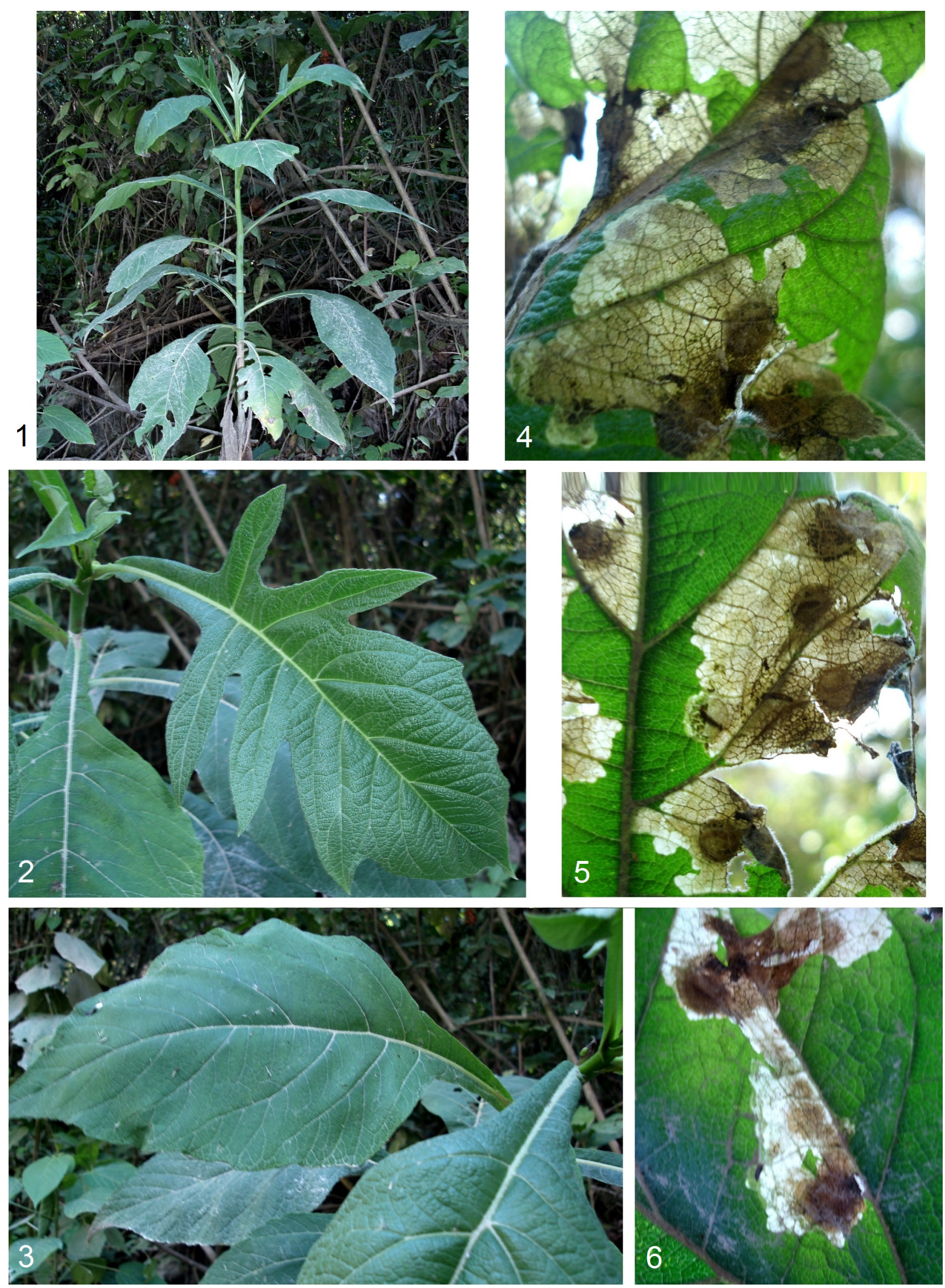

FIGURES 1-6. Bionomics of Astrotischeria mystica Diškus \& Stonis, sp. nov. 1-3, host plant Verbesina L. (possibly V. plowmanii Sagást.) (Asteraceae), Urubamba Province, Peru, 2180 m; 4-6, leaf mines 

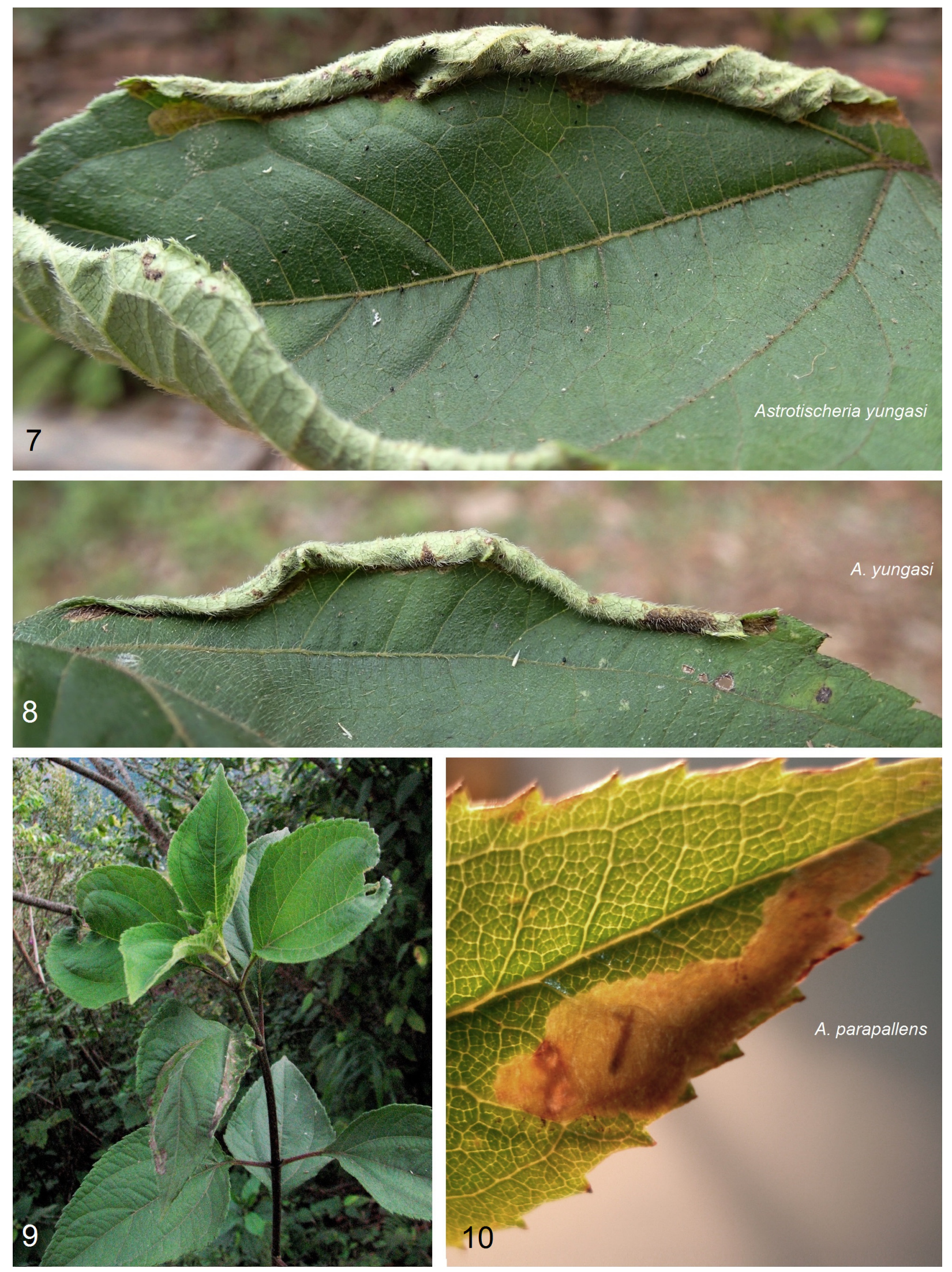

FIGURES 7-10. Bionomics of new Astrotischeria species. 7, 8, leaf mines of A. yungasi Diškus \& Stonis, sp. nov.; 9, Oyedaea DC., possibly O. boliviana (Lam.) King \& Rob. (Asteraceae), a host plant of A. yungasi sp. nov., Bolivia, Nor Yungas Province, 1660 m; 10, a leaf mine of A. parapallens Diškus \& Stonis, sp. nov. on Baccharis sp., possibly B. latifolia (Ruiz \& Pav.) Pers. (Asteraceae), Ayacucho, Peru, $2510 \mathrm{~m}$ 

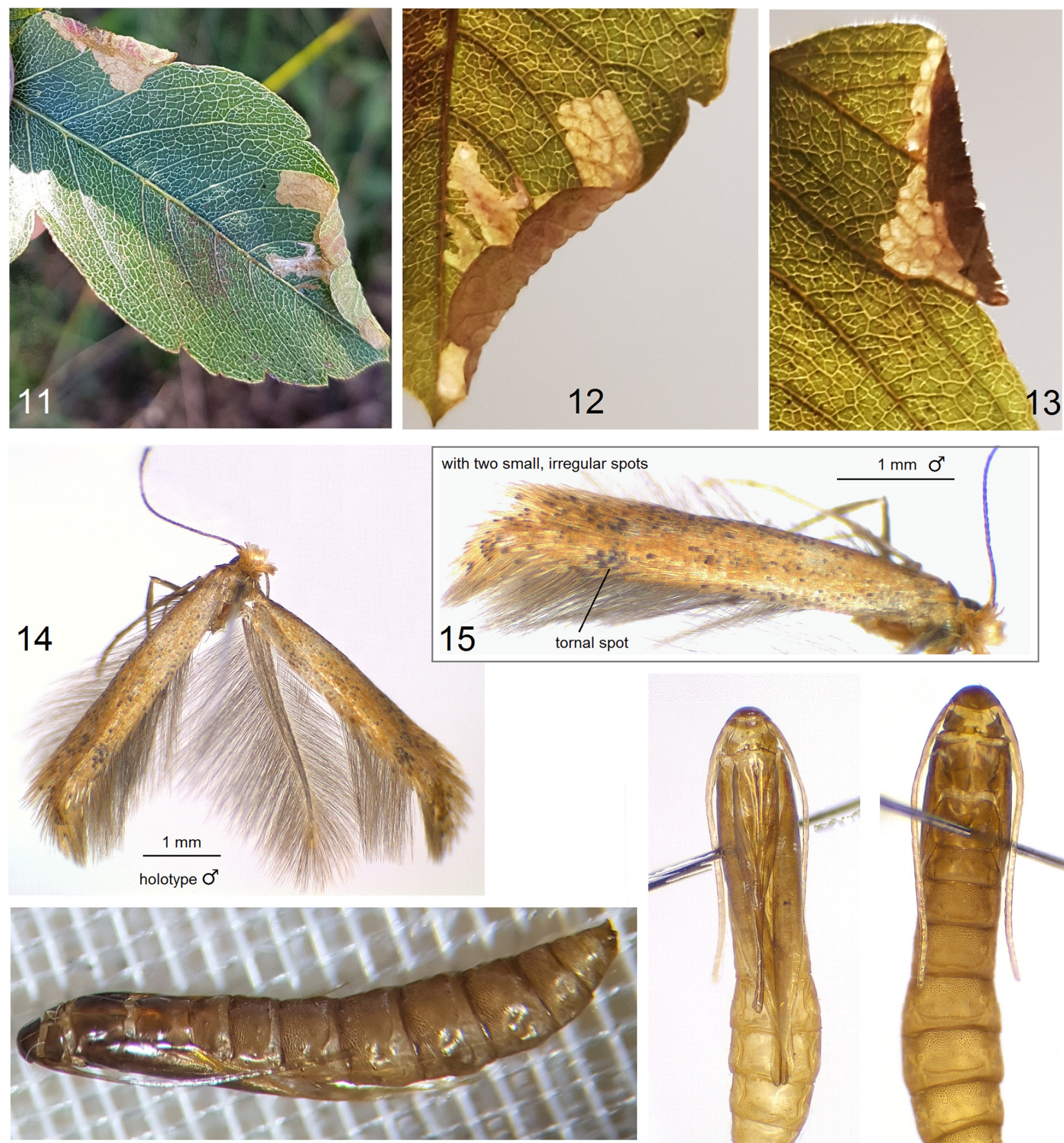

16
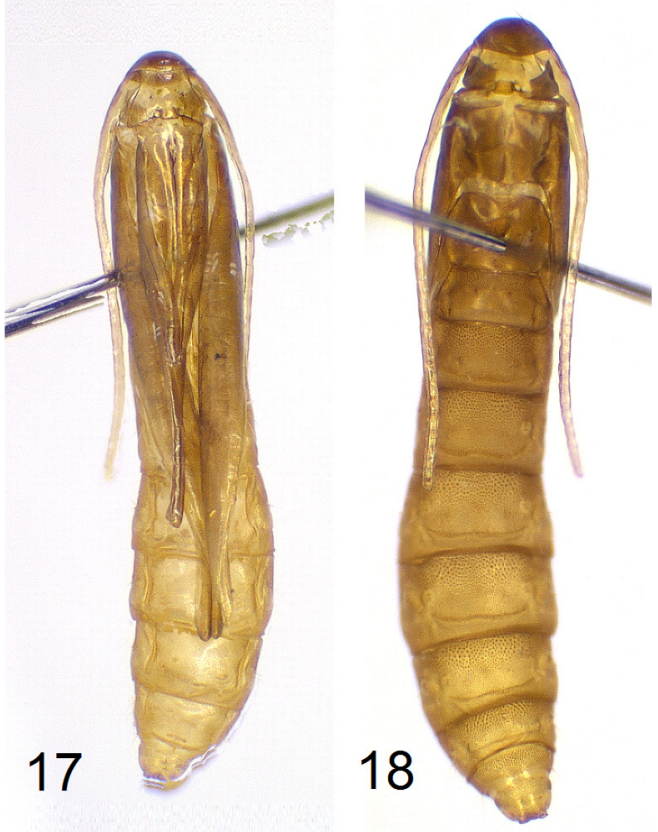

FIGURES 11-18. Astrotischeria serjaniphaga Remeikis \& Stonis, sp. nov. 11-13, leaf mines on Serjania Mill., possibly S. squarrosa Radlk. (Sapindaceae), Curahuasi, Apurímac Department, central Peru, at an elevation of about 2700 m; 14, 15, male adult, holotype; 16-18 pupal exuviae (NRC)

Thorax. Tegula, thorax, and forewing concolorous, glossy, dark golden ochre, sparsely speckled with dark greybrown scales; forewing with two small, irregular, subapical spots; the tornal spot is indistinctive (Fig. 15); fringe ochre, with incomplete and inconspicuous fringe line comprised of dark brown scales; forewing underside grey, golden glossy, with weak purple iridescence, without spots or androconia. Hindwing pale grey to grey on upper side and underside, with weak purple iridescence, without androconia; fringe grey, ochre glossy. Legs pale yellow-ochre, dark grey to blackish grey on upper side. Abdomen lost.

Female. Unknown. 
DNA barcode. We barcoded hind legs of the holotype. The aligned length of the dataset is $674 \mathrm{bp}$ : AACATTATATTTTATTTTTGGTATGTGAGCAGGTATAGTAGGAACATCATTAAGATTATTAATTCGAGCAGAATTAGGAACTGCAGGATCCTTAATTGGAGATGATCAAATTTATAACACTATTGTTACAGCCCATGCTTTTATTATAATTTTTTTTATAGTTATGCCAATTATAATTGGAGGATTTGGTAATTGATTAG TTCCATTAATATTAGGTGCCCCTGATATAGCATTCCCCCGTCTTAATAATATAAGATTTTGATTATTACCTCCATCTTTATTACTTTTAATTTCCAGAAGAATTGTAGAAAATGGAGCAGGAACTGGATGAACAGTATACCCCCCACTTTCATCAAATATTGCCCATACAGGAAGATCAGTAGATCTTGCTATTTTTTCC CTTCATTTAGCTGGAATTTCTTCAATTTTAGGAGCTATTAATTTTATTACTACAATAATTAATATACGATCACAAGGAATATCATTTGATCAAATACCTTTATTCGTATGAGCAGTTGCAATTACAACAGTATTATTATTATTATCTTTACCTGTTTTAGCTGGTGCTATTACAATATTATTAACAGATCGTAATTTAAACACATCTTTTTTTGATCCTGCTGGAGGAGGAGACCCTATTTTATATCAACATTTATTTTGATTTTTTGGTCATC. Sequence is available in GenBank under voucher/sample ID OK017167.

Bionomics (Figs. 11-13, 16-18). Host plant is Serjania Mill., possibly S. squarrosa Radlk. (Sapindaceae). Larvae mine leaves in May. The blotch mine (Figs. 11-13) is irregular, white at the beginning, cream, transparent, with no or very little frass further along; fully developed mines usually bend (distort) the mined leaf (Fig. 11). Pupation inside the leaf mine. Adults fly in June.

Distribution. The species is known from the single locality, Curahuasi, Dept. Apurímac, central Peru, at an elevation of about $2700 \mathrm{~m}$.

Etymology. The species is named after the host-plant genus Serjania, Sapindaceae, a novel host-plant taxon for the Tischeriidae, combined with the Ancient Greek phago (eater, feeder).

Remarks. Unpublished molecular data of mtDNA COI sequences provide strong support for this new species. In our unpublished molecular analysis of Tischeriidae, C. serjaniphaga sp. nov. always appeared as a very distinct, separate clade, close but not fully matching with Coptotriche. A phylogenetic tree will be published separately with a molecular analysis of Tischeriidae (Stonis et al. in prep.).

\section{Astrotischeria mystica Diškus \& Stonis, sp. nov.}

urn:Isid:zoobank.org:act:0F29E8C8-94B3-4B06-8C9E-30FF3FA36AB3

(Figs. 1-6, 19-22, 30-34, 49, 50)

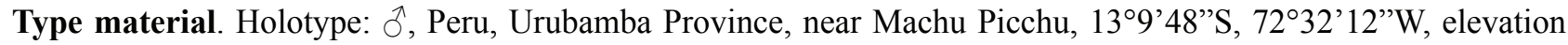
ca. $2180 \mathrm{~m}$, from feeding larvae 19.x.2008, ex pupa xi.2008, field card no. 4944, leg. A. Diškus, genitalia slide no. AD1050 (ZIN). Paratypes $4 \hat{\partial}, 2$ ㅇ, same label data as holotype, genitalia slide nos. AD1048 $\hat{\partial}$, AD1049우, AD1051 ( $\mathrm{ZIN}) ; 1 \hat{\jmath}$, same label data, genitalia slide no. AD1047 $\hat{\jmath}$ (from adult in pupal exuvia) (NRC).

Diagnosis. Only the male genitalia provide reliable diagnostics: the combination of a unique-shaped uncus (see Figs. 30, 32), and abruptly bent dorsal lobe of the valva (Fig. 30) with distal spine-like process (Fig. 34) distinguishes A. mystica sp. nov. from all other Astrotischeria species.

Male (Figs. 19-21). Forewing length 4.1-4.5 mm; wingspan 9.0-9.8 mm $(\mathrm{n}=5)$.

Head. Frons, palpi, and pectens pale ochre yellow to bright ochre, occasionally ochreous cream; frontal tuft and collar comprised of brownish grey, pale-tipped lamellar scales; antenna slightly longer than one half the length of forewing; flagellum dark brown, annulated with ochre cream; sensilla relatively short, very fine, inconspicuous.

Thorax. Tegula and thorax densely covered with grey-brown, ochre-tipped scales or entirely dark grey-brown. Forewing densely speckled with grey-brown and dark grey-brown scales and small, irregular spots of bright yellowish ochre scales; fringe dark grey, apically brown-ochre; fringe line absent or incomplete, comprised of dark brown or black-brown scales; forewing underside dark grey-brown, without spots or androconia. Hindwing dark brown to grey-brown on upper side and underside, without androconia; fringe brown to grey. Legs grey-brown to dark grey-brown.

Abdomen. Brownish grey on upper side and underside, ochre glossy distally on underside; anal tufts dorsal, long, dark grey; genital plates brownish grey. Genitalia (Figs. 30-34) with capsule 420-455 $\mu \mathrm{m}$ long (or $585 \mu \mathrm{m}$ long if measured from valval tips to vinculum), $260 \mu \mathrm{m}$ wide. Uncus (Figs. 30, 32) comprised of two sets of short but wide lobes. Valva (Figs. 30, 31) about $420 \mu \mathrm{m}$ long (excluding the basal process); dorsal lobe wide and with spine-like processes distally (see Fig. 34). Anellus only slightly thickened, mostly membranous, inconspicuous. 
Vinculum rounded (Figs. 30, 31). Phallus $360 \mu \mathrm{m}$ long, deeply bifurcated, symmetrical, with a large spine on each apical lobe (Figs. 30, 33).
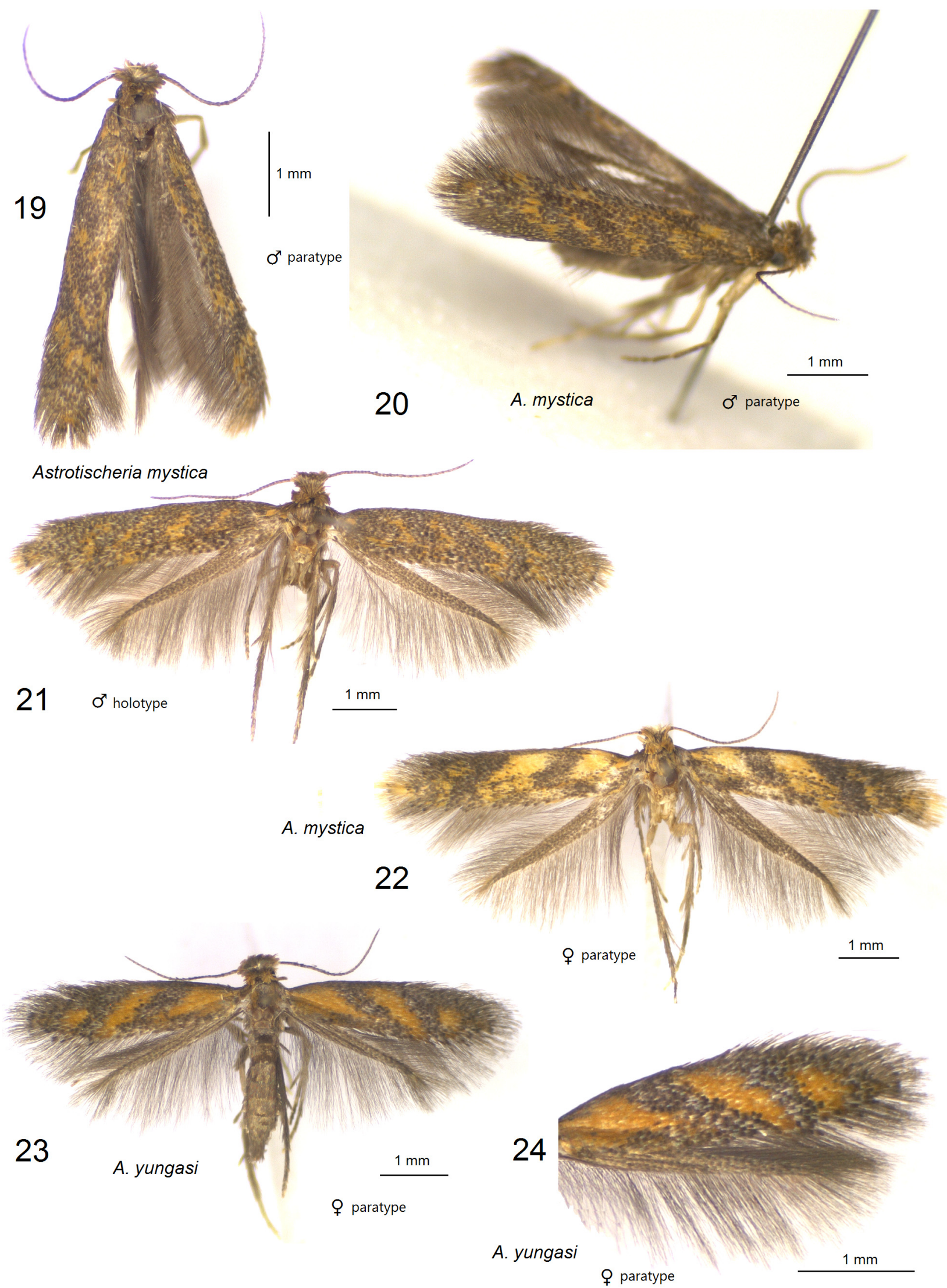

FIGURES 19-24. Adults of new Astrotischeria species. 19-22, Astrotischeria mystica Diškus \& Stonis, sp. nov.; 23, 24, Astrotischeria yungasi Diškus \& Stonis, sp. nov. (ZIN) 
Female (Fig. 22). Forewing length $4.5 \mathrm{~mm}$; wingspan $9.9 \mathrm{~mm}(\mathrm{n}=2)$.

Head. Similar to male. Antenna bright yellow-ochre in basal 1/5.

Thorax. Forewing grey-brown with two very large and two-four small, bright ochre-yellow spots; fringe widely yellow-ochre apically, grey-brown on tornus. Legs metallic glossy, brownish grey to dark brown with some yellowish ochre scales.

Abdomen. Genitalia (Figs. 49, 50) about $2210 \mu \mathrm{m}$ long. Ovipositor lobes small, rounded, clothed with short, modified setae ('peg setae'); area between ovipositor lobes relatively wide, with tiny papillae and some short setae. Second pair of lobes, lateral and anterior to the ovipositor lobes, twice smaller than ovipositor lobes, but bearing very long lamellar but slender setae. Anterior and posterior apophyses almost equal in length; prela comprised of three pairs of unique projections (Fig. 49). Corpus bursae very long and slender, without pectinations or signum. Accessory sac small, rounded. Ductus spermathecae very slender, with about 4 large coils and indistinctive, platelike vesicle.

Bionomics. Host plant is Verbesina L., possibly V. plowmanii Sagást. (Asteraceae) (Figs. 1-3). Larvae mine leaves and produce blotch-like leaf mines (Figs. 4-6). Pupation in a circular nidus inside the leaf mine (Fig. 5). Adults occur in November. Otherwise, the biology is unknown.

Distribution. The species is known from the single locality in Urubamba Province (near Machu Picchu), Peru, at an elevation of about $2180 \mathrm{~m}$.

Etymology. The species name is derived from the Ancient Greek mysticus (mysterious), for the unusual dorsal lobe of the valva in the male genitalia.

Astrotischeria yungasi Diškus \& Stonis, sp. nov.

urn:lsid:zoobank.org:act:5B1F462D-AB48-4D8B-A874-AB6E517825DF

(Figs. 7-9, 23, 24, 35-40, 47, 48)

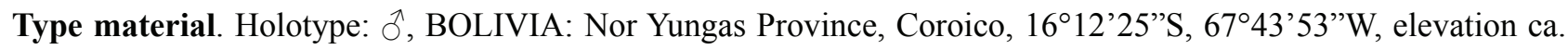
$1660 \mathrm{~m}$, from feeding larva 15.vi.2018, field card no. 5268, leg. A. Diškus, J. R. Stonis, slide no. AD1070 (from

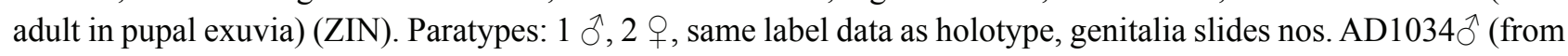
adult in pupal exuvia), AD1068 9 (ZIN); $1 \hat{\jmath}$, same label data, genitalia slide no. AD1069 $\hat{\partial}$ (from adult in pupal exuvia) (NRC).

Diagnosis. Externally, this new species can be confused with other speckled Astrotischeria species, including A. mystica sp. nov. and A. parapallens sp. nov. (both described herein), but $A$. yungasi sp. nov. is slightly darker and smaller, 7.2-7.6 mm in wingspan. In the male genitalia, A. yungasi is the most similar to A. dondavisi Stonis \& Diškus (see Stonis et al. 2019a) and A. truncata Diškus \& Stonis (see Stonis et al. 2018). From the latter, yungasi differs in the absence of a short, truncated basal lobe of the valva, long vinculum, and the wide uncus. From A. dondavisi, A. truncata differs in the long vinculum, large dorsal lobes of the valva, large lobes of the uncus, and slender base of the phallus. In the female genitalia, character validity would be speculative because many Astrotischeria females are unknown and are undiscovered. Also see Remarks.

Male (see Remarks). Genitalia (Figs. 35-40) with capsule 540-580 $\mu \mathrm{m}$ long, 210-225 $\mu \mathrm{m}$ wide. Uncus (Figs. $35,36)$ comprised of four lobes: two wide dorsal and two slender and slightly shorter ventro-lateral lobes. Valva (Figs. 35, 37, 39) about $305 \mu \mathrm{m}$ long (excluding the basal process); two dorsal lobes greatly developed (see Fig. 39); basal process of valva long (Fig. 39). Anellus indistinctive, mostly membranous, with 2-3 setae laterally (Fig. 40). Vinculum long, distally rounded. Phallus about $610 \mu \mathrm{m}$ long, distally with two long and slender lobes (Fig. 38).

Female (Figs. 23, 24). Forewing length 3.3-3.5 mm; wingspan 7.2-7.6 mm $(\mathrm{n}=2)$.

Head. Frons, palpi, and pectens pale yellow-ochre; frontal tuft comprised of distinctly wide, very glossy scales with some purple iridescence; frontal tuft metallic grey medially, dark golden yellow laterally and distally; collar pale ochre, inconspicuous; antenna slightly longer than one half the length of forewing; flagellum grey to blackish grey, sometimes indistinctly annulated with grey-cream.

Thorax. Tegula dark grey with purple iridescence, distally pale ochre; thorax pale ochre to bright ochre, sometimes grey medially. Forewing densely speckled with blackish grey or dark brown scales with some purple iridescence; three large oblique spots comprised of bright, very intense, yellow-ochre scales; fringe blackish grey; fringe 
line comprised of blackish brown scales; forewing underside dark grey-brown to blackish grey, without spots or androconia. Hindwing dark grey on upper side and underside, without androconia; fringe grey. Legs glossy grey, forelegs black-grey on upper side.

Abdomen. Very glossy, with some purple iridescence, metallic grey on upper side and underside, distally with pale ochre cream gloss on underside; genital segments grey. Genitalia (Figs. 47, 48) about $1250 \mu \mathrm{m}$ long. Ovipositor lobes small, oval, clothed with short, modified setae ('peg setae'); area between ovipositor lobes relatively wide, with tiny papillae and some short setae. Second pair of lobes, lateral and anterior to the ovipositor lobes, very small, bearing a few very long slender setae, without stout, modified 'peg setae'. Posterior and anterior apophyses almost equal in length; prela comprised of three pairs of unique, rod-like projections. Corpus bursae long and narrow, distally oval-shaped (Fig. 47), without pectinations or signum. Accessory sac inconspicuous, oval-shaped; ductus spermathecae very slender with 3 or 4 very large coils.

Bionomics (Figs. 7-9). Host plant is Oyedaea DC. (Asteraceae), most likely the species O. boliviana Britton, which grows in this region of Bolivia (Fig. 9). Larvae mine leaves in June. The blotch mine (Figs. 7, 8) is very long, developed along the leaf margin; at the final stage the mine bends (distorts) the leaf (Figs. 7, 8). Pupation inside the leaf mine. Adults occur in late June-July. Otherwise, biology is unknown.

Distribution. The species is known from the single locality in Bolivia (Nor Yungas Province: Coroico) at an elevation of about $1660 \mathrm{~m}$.

Etymology. The species is named after the Nor Yungas Province where it was discovered.

Remarks. The external species description is based exclusively on female adults since all three available males are known from pupal exuviae (no pinned male adults are preserved).

Our unpublished molecular study shows A. yungasi sp. nov., A. dondavisi Stonis \& Diškus and A. truncata Diškus \& Stonis as three separate species; a phylogenetic tree will be published separately with a molecular analysis of Tischeriidae (Stonis et al. in prep.).

\section{Astrotischeria parapallens Diškus \& Stonis, sp. nov.}

urn:Isid:zoobank.org:act:3AE6711C-34C4-404D-BEFD-F29C9C048B02

(Figs. 10, 25-29, 41-46, 51, 52)

Type material. Holotype: ${ }^{7}$, PERU: Huamanga Province, $9 \mathrm{~km}$ East of Ayacucho (Muyurina), 136'52"S, 74¹ '47'W, elevation ca. 2510 m, mining larva on Baccharis sp. (Asteraceae), 29.x.2008, ex pupa xi.2008, field card no. 4957, leg. A. Diškus, genitalia slide no. AD1045 (ZIN). Paratypes: $7 \hat{\jmath}, 4$, , same label data as holotype, genitalia slide nos. $\mathrm{AD} 1046 \hat{\jmath}, \mathrm{AD} 1052 \hat{\jmath}, \mathrm{AD} 864$ 우 (forewing venation), $\mathrm{AD} 973$ 우, $\mathrm{AD} 1042$ 우 $(\mathrm{ZIN}) ; 1 \hat{\jmath}, 1$ 우, same label data (NRC).

Diagnosis. Externally, this new species can be confused with some other speckled Astrotischeria species, including A. mystica sp. nov. described above. In the male genitalia, this species is the most similar to and probably closely related to A. pallens Puplesis \& Diškus from Neuquén, Argentina (described and illustrated in Puplesis \& Diškus 2003: figs. 263-265). However, A. parapallens Diškus \& Stonis, sp. nov. differs from A. pallens in the distally wide and dentate dorsal lobe of the valva (see Fig. 42), large apical lobes of the phallus (Figs. 44-46), very large soccii, and the significantly longer and slender uncus. Additionally, A. parapallens sp. nov. also differs from A. pallens in the dark forewing (the forewing of A. pallens is very pale, almost cream).

Male (Figs. 25-27). Forewing length 3.9-4.0 mm; wingspan 8.4-8.6 mm $(\mathrm{n}=9)$.

Head. Frons and palpi ochreous cream; pecten greyish cream; frontal tuft comprised of lamellar scales, brownish grey with some purple iridescence, sometimes with ochre-tipped scales; collar comprised of lamellar scales, glossy, pale brown-grey; antenna slightly longer than half the length of forewing; flagellum grey-brown on upper side and underside, sensilla relatively short, inconspicuous.

Thorax. Tegula and thorax grey-brown. Forewing densely speckled with grey-brown (sometimes black-brown) scales and small, irregular spots of ochre cream scales; occasionally spots large and comprised of pale ochre yellow scales (Fig. 27); fringe brownish grey to dark grey-brown, without fringe line; forewing underside grey-brown, without spots or androconia. Hindwing brownish grey to grey-brown on upper side and underside, without androconia; fringe brownish grey with some purple iridescence. Legs glossy grey-brown to pale grey, with some purple iridescence. 


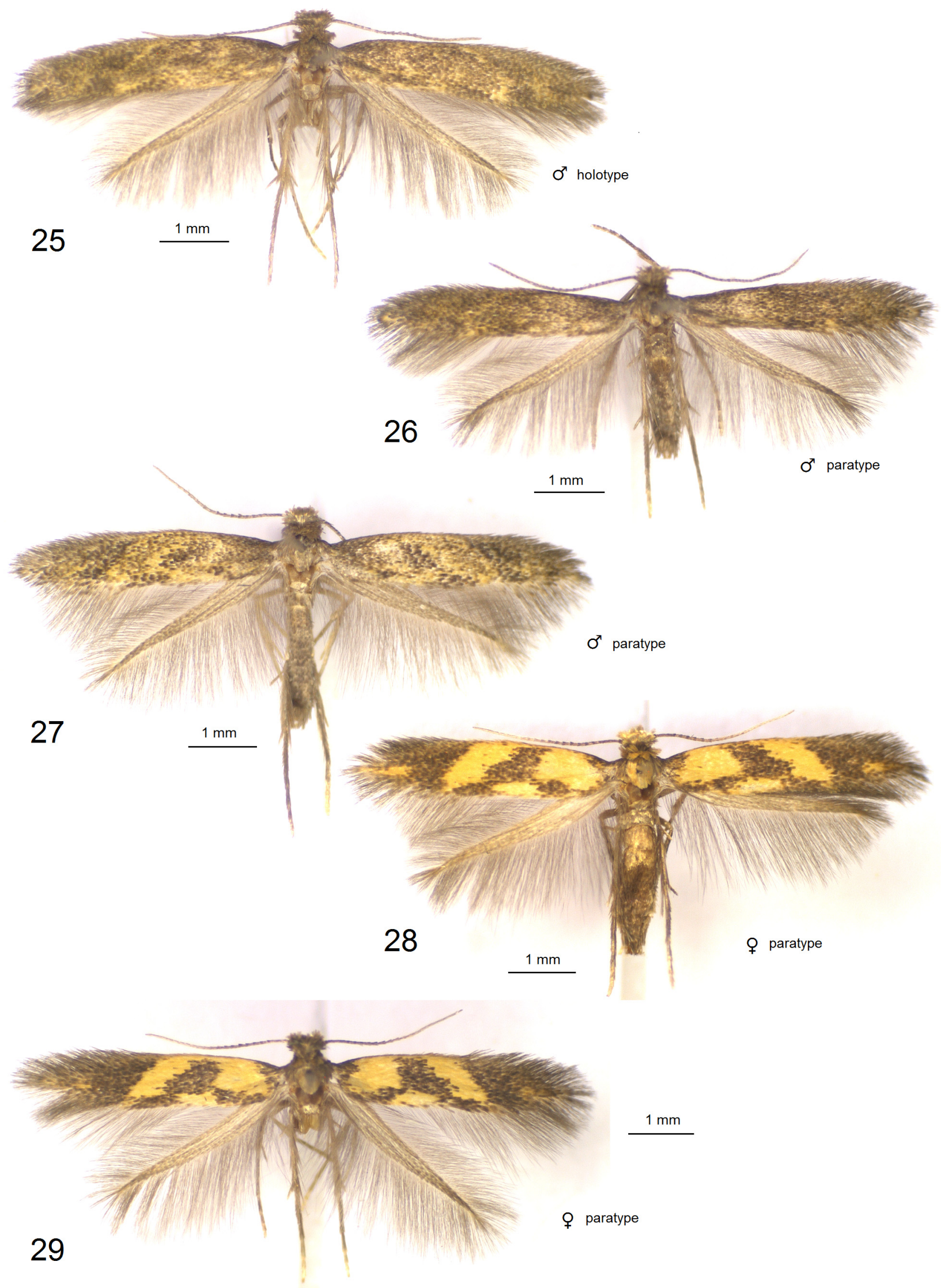

FIGURES 25-29. Adults of Astrotischeria parapallens Diškus \& Stonis, sp. nov. (ZIN) 


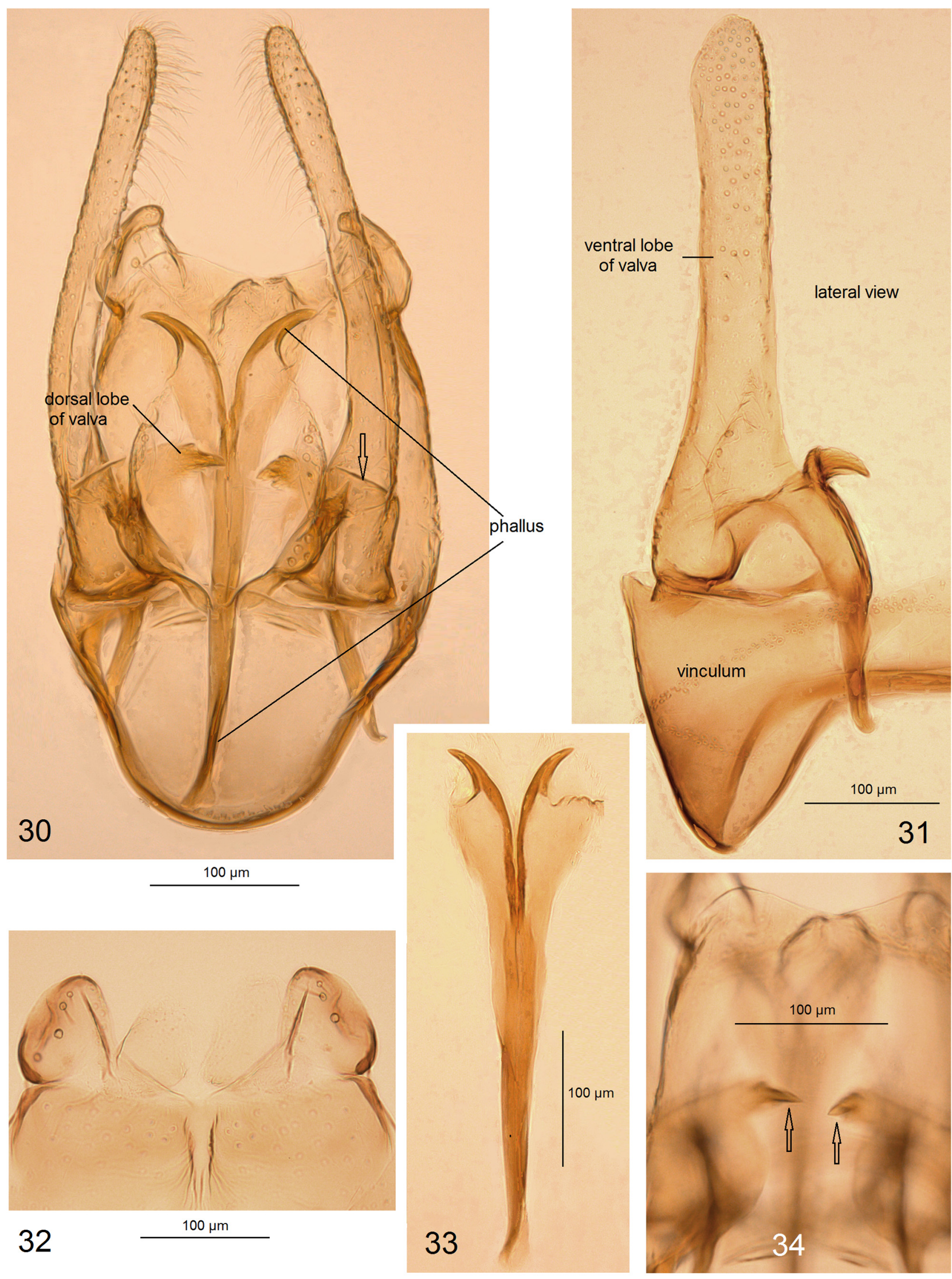

FIGURES 30-34. Male genitalia of Astrotischeria mystica Diškus \& Stonis, sp. nov. 30, capsule with phallus inside, holotype, genitalia slide no. AD1050; 31, lateral view of valva and vinculum, paratype, genitalia slide no. AD1047; 32, uncus, paratype, genitalia slide no. AD1047; 33, phallus, paratype, genitalia slide AD1047; 34, spine-like processes on dorsal lobes of valvae, holotype, genitalia slide no. 1050 (ZIN) 

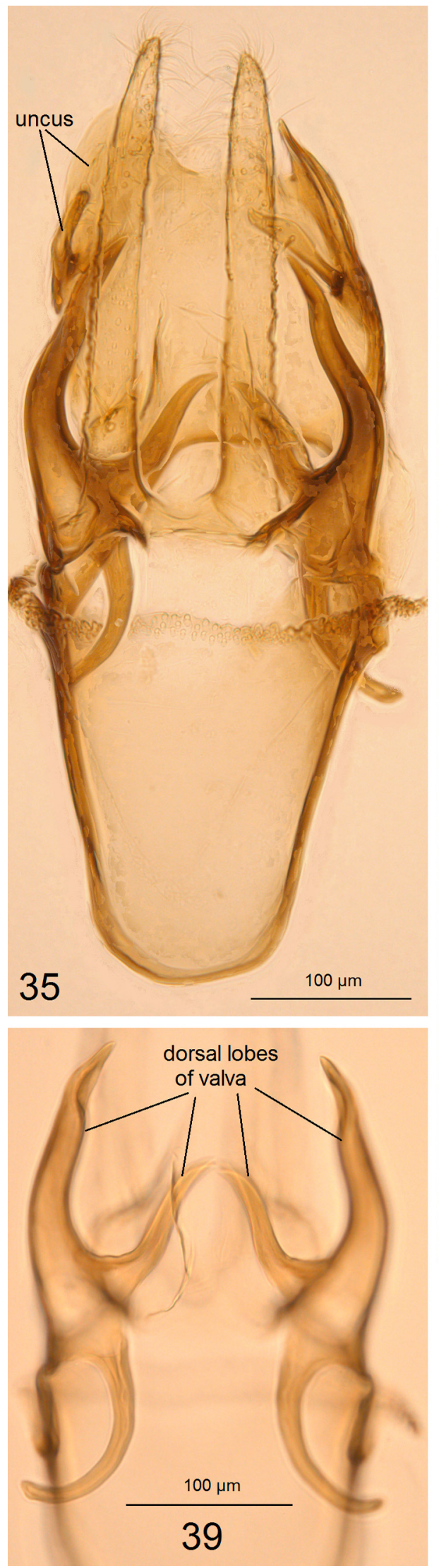

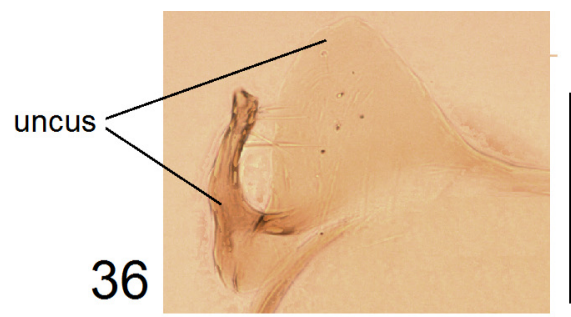

$100 \mu \mathrm{m}$
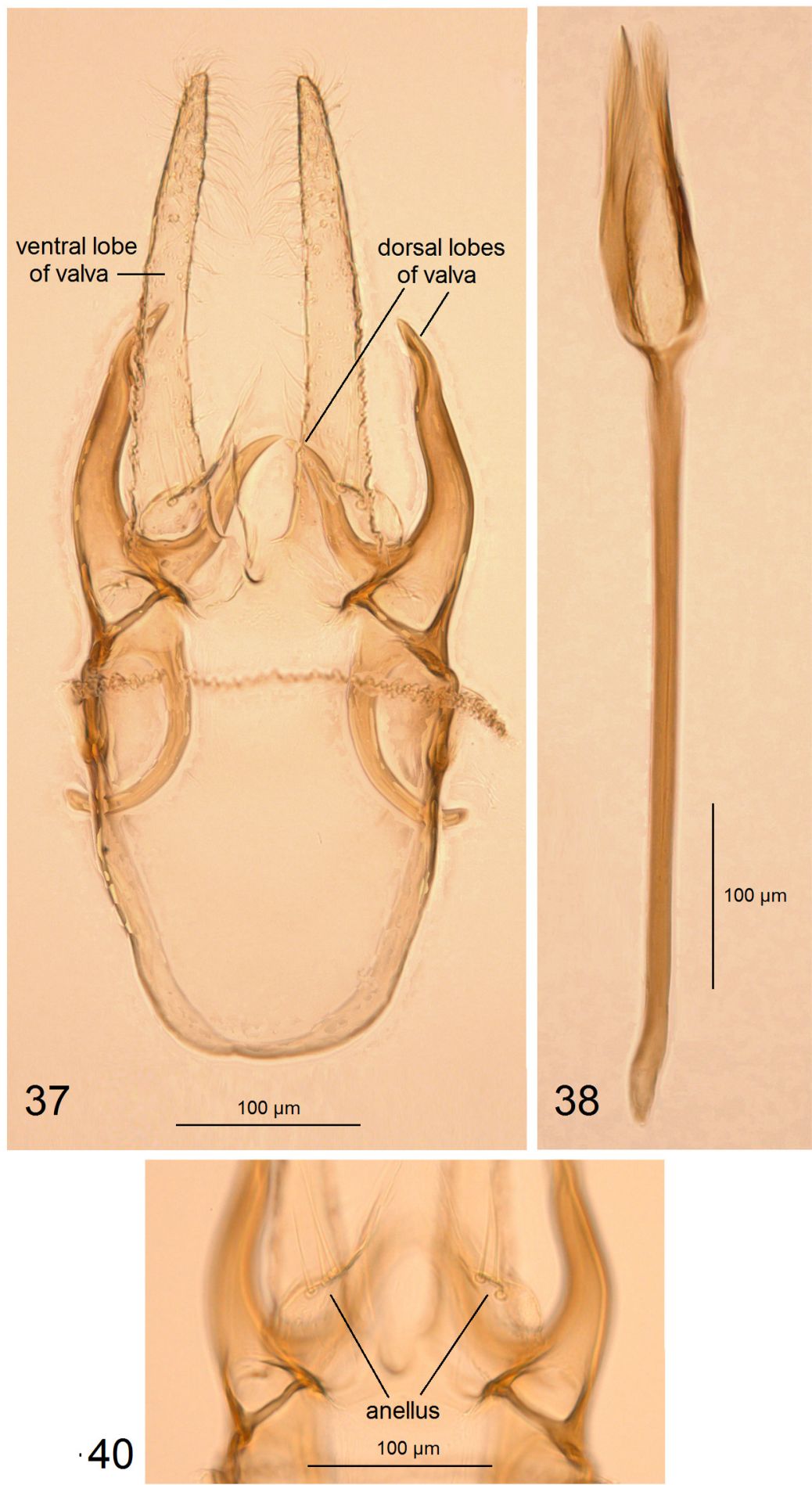

FIGURES 35-40. Male genitalia of Astrotischeria yungasi Diškus \& Stonis, sp. nov. 35, capsule with phallus removed, holotype, genitalia slide no. AD1070; 36, uncus, paratype, genitalia slide no. AD1034; 37, valvae and vinculum, paratype, genitalia slide no. AD1034; 38, phallus, holotype, genitalia slide AD1070; 39, 40, details of capsule, paratype, genitalia slide no. 1034 $(\mathrm{ZIN})$ 

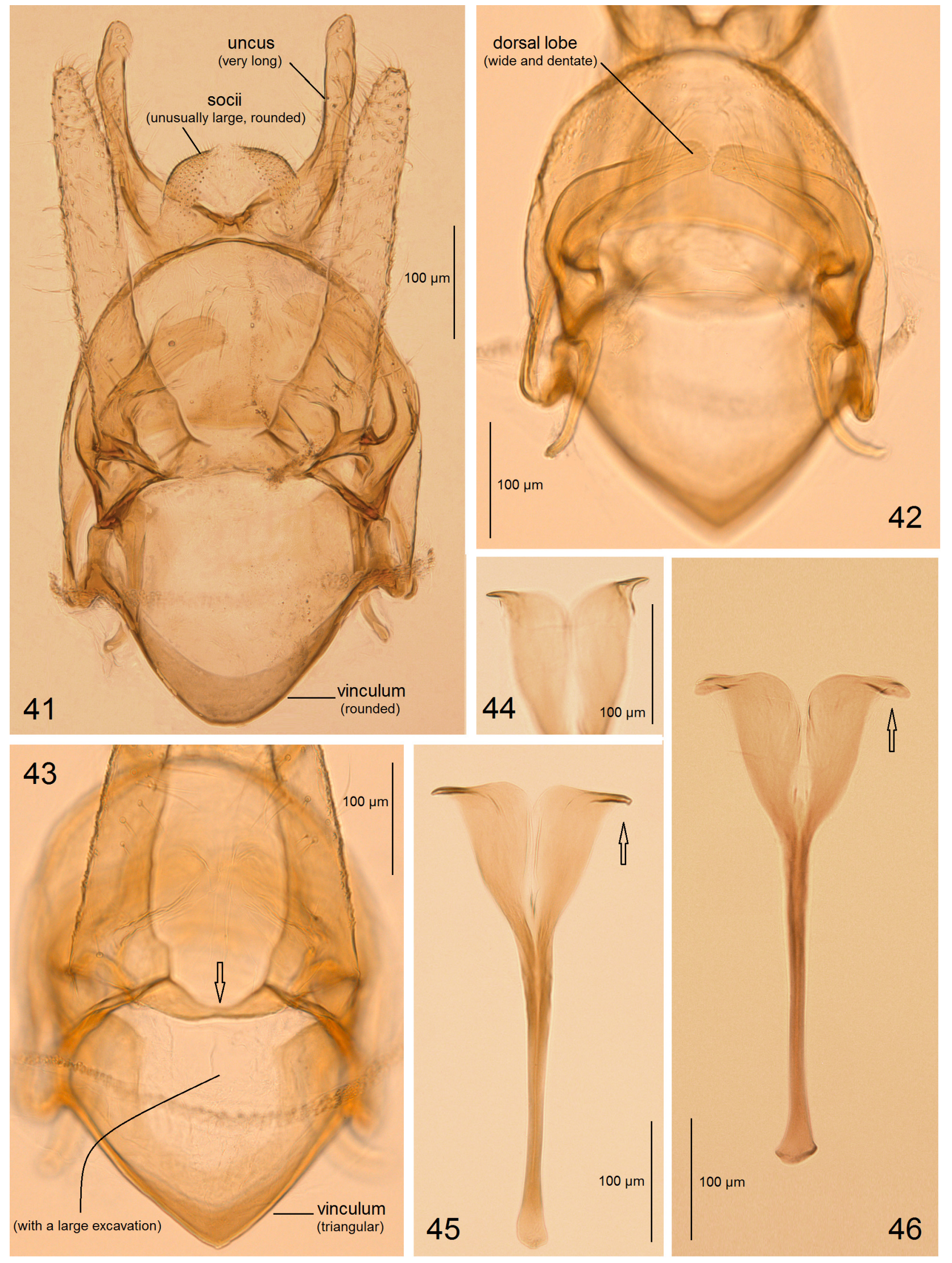

FIGURES 41-46. Male genitalia of Astrotischeria parapallens Diškus \& Stonis, sp. nov. 41, capsule with phallus removed, holotype, genitalia slide no. AD1045; 42, dorsal lobes of valvae, paratype, genitalia slide no. AD1052; 43, basally connected valvae and vinculum, paratype, genitalia slide no. AD1052; 44, apex of phallus, paratype, genitalia slide AD1052; 45, general view of phallus, paratype, genitalia slide no. 1046; 46, same, holotype, genitalia slide no. AD1045 (ZIN) 


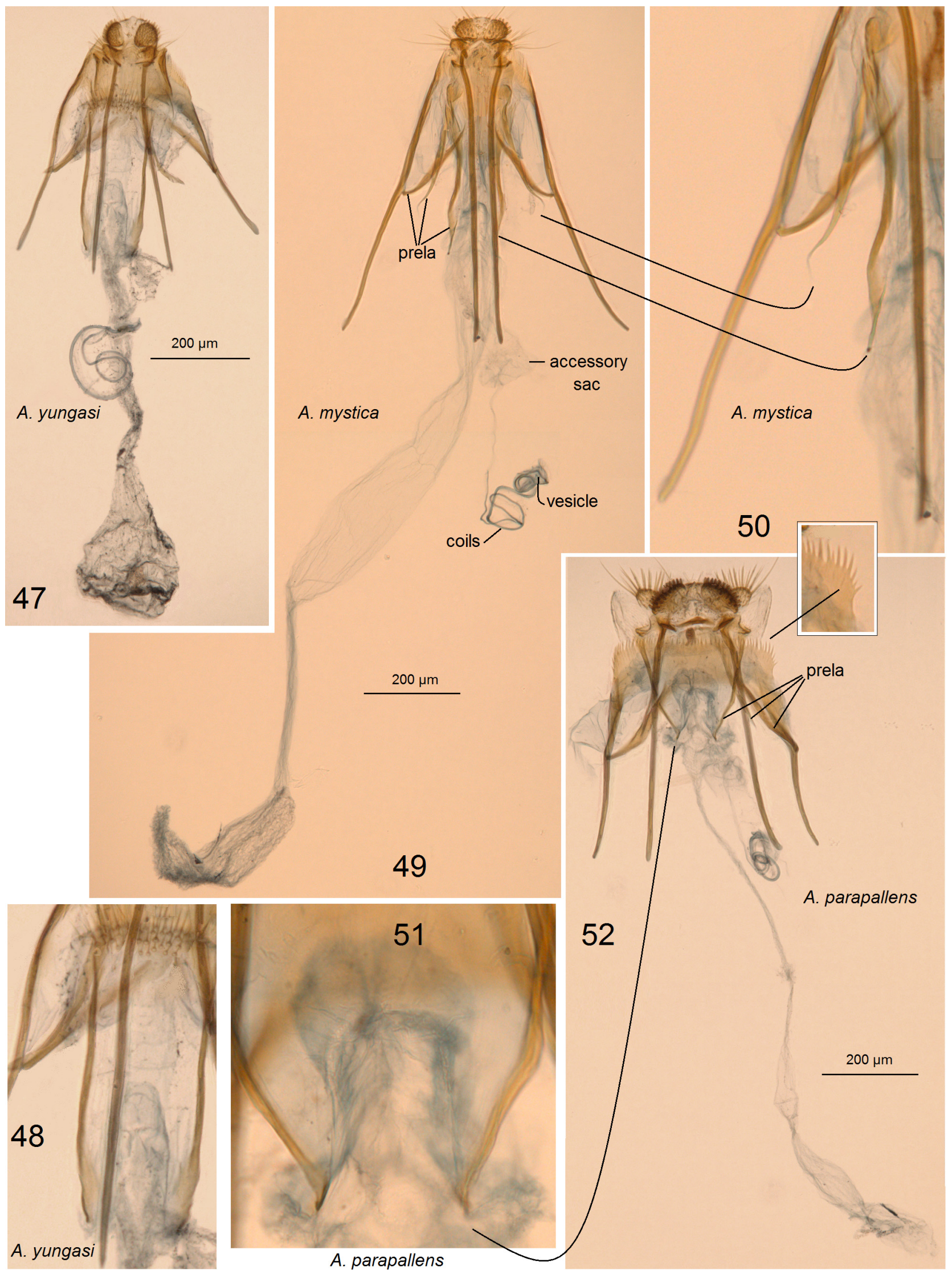

FIGURES 47-52. Female genitalia of new Astrotischeria species. 47, 48, A. yungasi Diškus \& Stonis, sp. nov., paratype, genitalia slide no. AD1068; 49, 50, A. mystica Diškus \& Stonis, sp. nov., paratype, genitalia slide no. AD1051; 51, 52, A. parapallens Diškus \& Stonis, sp. nov., paratype, genitalia slide no. AD1042 (ZIN) 

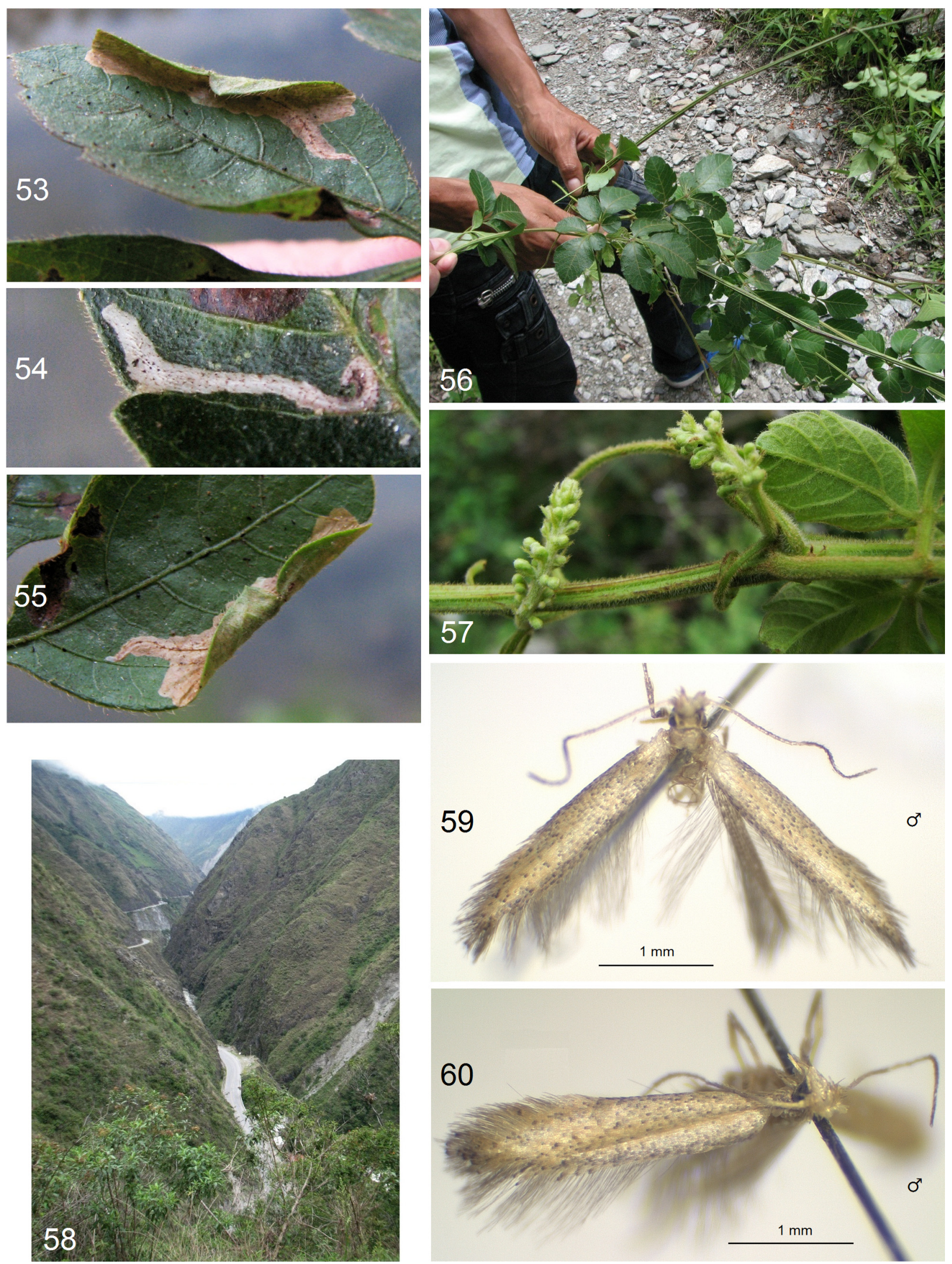

FIGURES 53-60. Leaf mines and adults. 53-55, leaf mines of Coptotriche sp. discovered on the eastern slopes of the Peruvian Andes; 56, 57, novel host plant, Serjania sp., possibly S. grandis Seem. (Sapindaceae); 58, habitat where the leaf mines were found on the eastern slopes of the Peruvian Andes (Huacapistana, NW of Carpapata, $2900 \mathrm{~m}$ ); 59, 60, male holotype of C. carmencita Stonis \& Diškus, a recently described species (Stonis et al. 2019a) discovered in the Peruvian "selva alta" (Ecological Park Fundo San José, La Merced, Junín Region, Peru, 840-900 m) 
Abdomen. Grey-brown to dark grey-brown on upper side, glossy brownish grey on underside; anal tufts dorsal, long, dark grey; genital plates brownish grey. Genitalia (Figs. 41-46) with capsule $595 \mu \mathrm{m}$ long, $300 \mu \mathrm{m}$ wide. Uncus (Fig. 41) comprised of two very large lobes. Valva (Figs. 41-43) about $335 \mu \mathrm{m}$ long (excluding the basal process); dorsal lobe wide and dentate distally (see Fig. 42). Anellus only slightly thickened, mostly membranous, with 2-3 small setae laterally. Vinculum rounded (Fig. 41) or triangular distally (Fig. 43). Phallus 380-405 $\mu \mathrm{m} \mathrm{long,}$ deeply bifurcated, symmetrical, with a spine on each apical lobe (Figs. 44-46).

Female (Figs. 28, 29). Forewing length 3.5-4.3 mm; wingspan 7.6-9.3 mm $(\mathrm{n}=5)$.

Head. Similar to male.

Thorax. Tegula grey-brown, distally ochre-yellow or entirely grey-brown. Thorax ochre-yellow to pale greybrown. Forewing grey-brown with three or four very large, ochre-yellow spots.

Abdomen. Genitalia (Figs. 51, 52) about $1580 \mu \mathrm{m}$ long. Ovipositor lobes unusually large, rounded, clothed with short, modified setae or 'peg setae'; area between ovipositor lobes wide, with tiny papillae and some short setae. Second pair of lobes, lateral and anterior to the ovipositor lobes, much three times smaller than ovipositor lobes, but bearing very long lamellar but slender setae. Anterior and posterior apophyses almost equal in length; prela comprised of three pairs of unique projections (Fig. 52). Corpus bursae long and very slender, without pectinations or signum. Accessory sac indistinctive. Ductus spermathecae very slender, with about 4 large coils and indistinctive vesicle.

Bionomics (Fig. 10). Host plant: Baccharis L., possibly B. latifolia (Ruiz \& Pav.) Pers. (Asteraceae). Larvae mine leaves in late October. The blotch mine (Fig. 10) is irregular, elongated, usually pale brownish, with little or no frass. Pupation inside the leaf mine. Adults occur in November.

Distribution. This species is known from the single locality in Peru (Ayacucho), at an elevation of about 2500 $\mathrm{m}$, but the host plants have a much broader distribution.

Etymology. The species is named after Astrotischeria pallens Puplesis \& Diškus from Argentina, in reference to the similar male genitalia.

\section{Discussion}

Documenting biological diversity. The ultimate task of biological systematics or taxonomy is to document and understand the extent and significance of biological diversity (Vane-Wright 1992, 1996). Description of new taxa is among the most critical of tasks in biodiversity studies. It has been particularly relevant recently because of complete destruction or severe fragmentation of habitats, unprecedented use of natural resources, heavy industrial pollution, and environmental threats due to climate change. Biodiversity of the planet, particularly of tropical and subtropical regions, is declining rapidly (see Hallmann et al. 2017; Leather 2018; Sánchez-Bayo \& Wyckhuys 2019; Zattara \& Aizen 2021) and, in many cases, transitioning to irreversible changes (Puplesis 2002; Bellard et al. 2012; Morton \& Hill 2014).

Efforts to study global biodiversity appears to be growing (Zhang 2008, 2011; Cutko 2009; La Salle et al. 2009; Pereira et al. 2010), but the task of global biodiversity assessment is far too immense considering the faster rate of habitat destruction in comparison to the much slower speed of biodiversity inventory research (Schmeller et al. 2017).

Not so long ago, leaf-mining moths from various lepidopteran families, were largely neglected in the tropical, and even some boreal, regions. However, taxonomic inventories of these tiny insects can provide knowledge about global biota and are essential as tools for prompt measures in the preservation of biodiversity (Dobrynina et al. 2021). For example, recently the Catalogue of Lepidoptera of Russia (Sinev 2019) revealed species composition of this geographically immense country, outlined geographical distribution of individual species, and determined least studied areas. With respect to the lepidopteran fauna, this work will serve as a very powerful impetus for further taxonomic and targeted faunistic research (Dobrynina et al. 2021).

With the development of new technologies and the need to complete biodiversity inventories faster, integration of DNA COI barcoding or other molecular methods into ongoing taxonomic inventories has been propagated (notably Janzen et al. 2009; Miller 2015; Miller et al. 2016; Aagaard et al. 2017). However, during the last few years, some very controversial attempts rejecting the usual standards for species description have been undertaken to speed species descriptions. Notably, the recent publication "Minimalist revision and description of 403 new species in 11 
subfamilies of Costa Rican braconid parasitoid wasps" (Sharkey et al. 2021) violates the basic rules of taxonomy (Meier et al. 2021).

Here, we disagree with the methods and approach by Sharkey et al. (2021), and adhere to the traditional standards for species descriptions. Following Ahrens et al. (2021), we advocate for "an integrated framework where new evidence is compatible with existing knowledge, and where competing hypotheses can be tested against each other in a framework of established, widely accepted and clearly specified scientific rules" (Ahrens et al. 2021).

Sapindaceae as a host-plant family of Tischeriidae. Sapindaceae, or the soapberry family, with about 138144 genera and 1858-1930 plant species globally, has a worldwide distribution. This family is well-known from the tropics and subtropics, and has many representatives in temperate regions (Acevedo-Rodríguez et al. 2011; Stevens 2017). Although there are many lepidopterans that feed on Sapindaceae (Robinson et al. 2010), so far there have been surprisingly few, only two, records of leaf-mining Tischeriidae feeding on this diverse plant family.

The first record of Sapindaceae-feeding Tischeriidae from Central America was the result of long-term fieldwork by Owen T. Lewis (University of Oxford, UK) in Las Cuevas, Belize, 1997-1998. During this fieldwork, one species was reared from Cardiospermum grandiflorum Sw., Sapindaceae (Stonis et al. 2020a). Larvae of this tischeriid species, Coptotriche singularis Stonis \& Diškus, are leaf miners, creating a rather typical blotch-type mine with a bent leaf margin, however, morphology of the male genitalia is unusual (Stonis \& Diškus 2008) and it seems that taxonomic transfer of $C$. singularis to another genus of Tischeriidae would be more logical and better supported (Stonis et al. in prep.).

The second published record of Sapindaceae-feeding Tischeriidae was the discovery of a northern Argentinian trumpet moth with doubtful taxonomic position, Paratischeria suprafasciata Diškus \& Stonis (Stonis et al. 2020b), that feeds on Allophylus edulis (A. St.-Hil., A. Juss. \& Cambess.) Hieron. ex Niederl. Allophylus edulis, with the indigenous names of "cocú" or "chal chal", is a South American shrub or little tree with red, edible fruits (Ferrucci 2004). The Sapindaceae family is economically important because it comprises several genera of trees and shrubs that produce edible fruits, and some genera, mainly lianas, are well known for their medicinal and flavoring properties. Toxic milky sap (saponins) of some lianas were traditionally used in tropical America as a source of poison for arrows used in hunting and fishing ("barbasco") (Acevedo-Rodríguez 1990; Beck 1990).

A novel host-plant genus, Serjania. Many sapindaceous lianas belong to the genus Serjania Mill. It is the largest genus in Sapindaceae and is comprised mostly of lianas or vines that produce milky sap and have bi- or triternately compound leaves accompanied by small stipules (for further characteristics see Weckerle \& Rutishauser 2005 and Acevedo-Rodriguez et al 2017). This genus is exclusively American in distribution, known from southern North America and the Caribbean to the southern part of South America, with important centres of taxonomic diversity in the highlands of Brazil and savannas of Mexico (Acevedo-Rodriguez 2018). The genus comprises about 215 (Porter \& Sytsma 2019) to 230 species occurring in tropical and subtropical habitats (Acevedo-Rodriguez 2018). They are known to be common in the forest canopy, in savannas, and disturbed open areas (Gentry 1991; AcevedoRodriguez 2018).

During our fieldwork in Peru, as part of the project "Rapid assessment of biodiversity plots of critical value in the provinces Chanchamayo and Satipo, Peru", we observed Serjania plants to be very common in many of the Andean areas we visited. Serjania plants are very well represented in the Andes of South America, growing mainly below $1500 \mathrm{~m}$, but some species occur up to 3000-3500 m. The genus is distributed in the Andes of Ecuador, Peru, and Bolivia, and Colombia (Obando 2015), and can grow in forest habitats that are adapted to dry conditions or savannas, and of high solar radiation (Dias et al. 2019; Schnitzer \& van der Heijden 2019).

We had already discovered larvae of new pygmy moths (Nepticulidae) feeding on Serjania at an altitude of about $1200 \mathrm{~m}$, and it was noteworthy that this new Nepticulidae species had a very strong morphological resemblance to a Rosaceae-feeding Stigmella from the Palaeartic region. Therefore, due to the historical paucity of hostplant feeding records of leaf-mining moths on Sapindaceae, it was exciting to discover that Serjania is a host plant for the Tischeriidae as well.

On Serjania, we discovered a Tischeriidae species from Curahuasi, Apurímac Department, central Peru, at an elevation of about $2700 \mathrm{~m}$. In our unpublished, preliminary molecular analysis of Tischeriidae, this species, Coptotriche serjaniphaga Remeikis \& Stonis, sp. nov. (described above), always groups close to Coptotriche species, but as a well-separated clade from many other species of this genus (Stonis et al. in prep.).

Additionally, on the eastern slopes of the Andes, Huacapistana, NW of Carpapata (Fig. 58), at elevation of about 2900 m, we discovered numerous Coptotriche leaf mines (Figs. 53-55) on Serjania, possibly S. grandis Seem. 
(Figs. 56, 57). Adults failed to emerge from the leaf mines, therefore the species was left unidentified and undescribed. However, at lower elevations in the same major canyon at the Peruvian "selva alta" (Ecological Park Fundo San José, La Merced, Junín Region) at an altitude of 840-900 m, C. carmencita Stonis \& Diškus (Figs. 59, 60) was attracted to a light trap, and subsequently described with the biology unknown (Stonis et al. 2019a). Serjania plants were also common at the collecting site of $C$. carmencita. Therefore, it is possible that a host plant of $C$. carmencita is Serjania sp. It is also possible that the leaf mines photographed at a close distance from the collecting site of $C$. carmencita, but at an altitude of $2900 \mathrm{~m}$ (Figs 53-55), may belong to C. carmencita.

By introducing a novel host plant genus for Tischeriidae, we conclude that Serjania is potentially a very important host plant for the Neotropical Tischeriidae. Our previous experience and observations of leaf mines on Serjania suggest that because of the sparse sampling, what we are seeing in the Neotropics is just the tip of the iceberg, and further search of leaf miners on Serjania has great potential, both as regards to a great taxonomic diversity and phylogenetic position of Serjania-feeding taxa. As a testament to our prediction, during the preparation of this paper and subsequent identification of some host plants, we found that there is at least another undescribed Tischeriidae species, similar to the Belizian C. singularis, which feeds either on Serjania Mill. or the closely related Paullinia L. (Sapindaceae) in Honduras.

\section{Acknowledgements}

We are indebted to our Ecuadorian, Peruvian, Colombian and Guatemalan scientific partners, including Julia Puplesyte-Chambers from the Environmental Programme at the Andes Office of NGO DAR Peru for initiation of training courses and a fieldwork on the project "Rapid assessment of biodiversity plots of critical value in the provinces Chanchamayo and Satipo, Peru, and Bolivia", in cooperation with the Baltic-American Biotaxonomy Institute in 2017-2018.

We are also grateful to an anonymous reviewer and Dr. Enrigue A. Mundaca (Universidad Católica del Maule, Chile) for their overview of the MS and suggestions. We are much indebted to Prof. Dr. Bong-Kyu Byun (Hannam University, South Korea), Science Editor of Zootaxa, for managing the editorial process and suggestions.

This research was partially funded by a grant (S-MIP-19-30, "DiagnoStics") from the Research Council of Lithuania.

The study by S. V. Baryshnikova was performed within the state research project AAAA-A19-119020690101-6.

José L. Fernández-Alonso thanks the Royal Botanical Garden - CSIC of Spain, for facilitating visits to herbaria and field work in South America under the CGL 2010-19747 project.

M. Alma Solis thanks Dr. Michael Gates, Research Leader, of the Systematic Entomology Laboratory, ARS, USDA, for supporting the participation of MAS in this research. Mention of trade names or commercial products in this publication is solely for the purpose of providing specific information and does not imply recommendation or endorsement by USDA. USDA is an equal opportunity provider and employer.

\section{References}

Aagaard, K., Berggren, K., Hebert, P.D.N., Sones, J., McClenaghan, B. \& Ekrem, T. (2017) Investigating suburban micromoth diversity using DNA barcoding of malaise trap samples. Urban Ecosystems, 20, 353-361. https://doi.org/10.1007/s11252-016-0597-2

Acevedo-Rodríguez, P. (1990) The occurrence of Piscicides and Stupefactants in the Plant Kingdom. Advances in Economic Botany, 8, 1-23. [https://www.jstor.org/stable/43927563]

Acevedo-Rodríguez, P. (2018) Guide to the genera of lianas and climbing plants in the Neotropics Sapindaceae. 20 pp. Available from: https://naturalhistory.si.edu/sites/default/files/media/file/sapindaceae_0.pdf (accessed 8 June 2021)

Acevedo-Rodríguez, P., van Welzen, P., Adema, F. \& van der Ham, R.W.J.M. (2011) Sapindaceae. In: Kubitzki, K. (Ed.), The Families and Genera of Vascular Plants. X. Flowering Plants: Eudicots. Sapindales, Cucurbitales, Myrtaceae. Springer, Heidelberg, New York, pp. 357-407. https://doi.org/10.1007/978-3-642-14397-7_17

Acevedo-Rodríguez, P., Wurdack, K.J., Ferrucci, M.S., Johnson, G., Dias, P., Coelho, R.G., Somner, G.V., Steinmann, V.W., Zimmer, E.A. \& Strong, M.T. (2017) Genetic relationships and classification of tribe Paullinieae (Sapindaceae) with a new concept of supertribe Paulliniodea. Systematic Botany, 42 (1), 96-114.

https://doi.org/10.1600/036364417X694926 
Ahrens, D., Ahyong, S.T., Ballerio, A., Barclay, M.V.L., Eberle, J., Espeland, M., Huber, B.A., Mengual, X., Pacheco, T.L., Peters, R.S., Rulik, B., Vaz-De-Mello, F., Wesener, T. \& Krell, F.-T. (2021) Is it time to describe new species without diagnoses?-A comment on Sharkey et al. (2021). Zootaxa, 5027 (2), 151-159.

https://doi.org/10.11646/zootaxa.5027.2.1.

Beck, H.T. (1990) A survey of useful species of Paullinia L. (Sapindaceae). Advances in Economic Botany, 8, 41-56. Available from: https://www.jstor.org/stable/43927566

Bellard, C., Bertelsmeier, C., Leadley, P., Thuiller, W. \& Courchamp, F. (2012) Impacts of climate change on the future of biodiversity. Ecology letters, 15 (4), 365-377. https://doi.org/10.1111\%2Fj.1461-0248.2011.01736.x

Braun, A.F. (1972) Tischeriidae of America North of Mexico (Microlepidoptera). Memoirs of the American Entomological Society, 28, 1-148.

Cutko, A. (2009) Biodiversity Inventory of Natural Lands: A How-To Manual for Foresters and Biologists. NatureServe, Arlington, Virginia, 32 pp. Available from: http://www.natureserve.org/biodiversity-science/publications/biodiversity-inventorynatural-lands-how-manual-foresters-and

Dias, A.S., Oliveira, R.S., Martins, F.R., Bongers, F., Anten, N.P.R. \& Sterck, F. (2019) How do lianas and trees change their vascular strategy in seasonal versus rain forest? Perspectives in Plant Ecology, Evolution and Systematics, 40, 125465 . https://doi.org/10.1016/j.ppees.2019.125465

Diškus, A. \& Stonis, J.R. (2012) Leaf-mining insects of Lithuania. The Nepticulidae (Lepidoptera): taxonomy, chorological composition and trophic relationships. Monograph. Lutute Publishers, Kaunas, 220 pp. [in Lithuanian]

Diškus, A. \& Stonis, J.R. (2015) Astrotischeria neotropicana sp. nov.—a leaf-miner on Sida, Malvaceae, currently with the broadest distribution range in the Neotropics (Lepidoptera, Tischeriidae). Zootaxa, 4039 (3), 456-466. https://doi.org/10.11646/zootaxa.4039.3.5

Dobrynina, V., Baryshnikova, S., Budrys, E., Rimšaite, J. \& Bidzilya, O. (2021) Taxonomic papers as published products of the biodiversity inventory: if not Impact Factor (IF) or Quartiles (Q), then what does determine their importance estimated on the basis of the Research Interest Score? Biologija, 67 (3). [published online] https://doi.org/10.6001/biologija.v67i2.4454

Ferrucci, M.S. (2004) Sapindaceae Juss. Aportes Botánicos de Salta, Serie Flora, 7 (4), 1-44. Available from: http://www.unsa. edu.ar/biblio/herbario/flora/vol7/pdf/4.\%20SAPINDACEAE.pdf

Gentry, A.H. (1991) The distribution and evolution of climbing plants. In: Putz, F.E. \& Mooney, H.A. (Eds.), The Biology of Vines. Cambridge University Press, Cambridge, pp. 3-50. https://doi.org/10.1017/CBO9780511897658.003

Hallmann, C.A., Sorg, M., Jongejans, E., Siepel, H., Hofland, N., Schwan, H. Stenmans, W., Müller, A., Sumser, H., Hörren, T., Goulson, D. \& de Kroon, H. (2017) More than 75 percent decline over 27 years in total flying insect biomass in protected areas. PLoS ONE, 12 (10), e 0185809. https://doi.org/10.1371/journal.pone.0185809

Janzen, D.H., Hallwachs, W., Blandin, P., Burns, J.M., Cadiou, J.M., Chacon, I., Dapkey, T., Deans, A.R., Epstein, M.E., Espinoza, B., Franclemont, J.G., Haber, W.A., Hajibabaei, M., Hall, J.P., Hebert, P.D., Gauld, I.D., Harvey, D.J., Hausmann, A., Kitching, I.J., Lafontaine, D., Landry, J.F., Lemaire, C., Miller, J.Y., Miller, J.S., Miller, L., Miller, S.E., Montero, J., Munroe, E., Green, S.R., Ratnasingham, S., Rawlins, J.E., Robbins, R.K., Rodriguez, J.J., Rougerie, R., Sharkey, M.J., Smith, M.A., Solis, M.A., Sullivan, J.B., Thiaucourt, P., Wahl, D.B., Weller, S.J., Whitfield, J.B., Willmott, K.R., Wood, D.M., Woodley, N.E. \& Wilson, J.J. (2009) Integration of DNA barcoding into an ongoing inventory of complex tropical biodiversity. Molecular Ecology Resources, 1, 1-26. https://doi.org/10.1111/j.1755-0998.2009.02628.x

La Salle, J., Wheeler, Q., Jackway, P., Winterton, S., Hobern, D. \& Lovell, D. (2009) Accelerating taxonomic discovery through automated character extraction. Zootaxa, 2217 (1), 43-55. https://doi.org/10.11646/zootaxa.2217.1.3

Leather, S. (2018) "Ecological Armageddon"-more evidence for the drastic decline in insect numbers. Annals of Applied Biology, $172(1), 1-3$. https://doi.org/10.1111/aab.12410

Meier, R., Blaimer, B., Buenaventura, E., Hartop, E., von Rintelen, T., Srivathsan, A. \& Yeo, D. (2021) A re-analysis of the data in Sharkey et al.'s (2021) minimalist revision reveals that BINs do not deserve names, but BOLD Systems needs a stronger commitment to open science. BioRxiv, 2021.04.28.441626. Available from: https://doi.org/10.1101/2021.04.28.441626 (accessed 14 June 2021)

Miller, S.E. (2015) 22 - DNA barcoding in floral and faunal research. In: Watson, M.F., Lyal, C.H.C. \& Pendry, C.A. (Eds.), Descriptive Taxonomy: the Foundation of Biodiversity Research. Cambridge University Press, Cambridge, pp. $296-311$. https://doi.org/10.1017/CBO9781139028004.028

Miller, S.E., Hausmann, A., Hallwachs, W. \& Janzen, D.H. (2016) Advancing taxonomy and bioinventories with DNA barcodes. Philosophical transactions of the Royal Society of London. Biological Sciences, 371 (1702), 20150339. https://doi.org/10.1098/rstb.2015.0339

Morton, S.R. \& Hill, R. (2014) What is biodiversity and why it is important? In: Morton, S.R., Sheppard, A.W. \& Lonsdale, 
W.M. (Eds.), Biodiversity, Science and Solutions for Australia, CSIRO Publishing, Collingwood, Melbourne, pp. 1-12. https://doi.org/10.1071/9781486302062

Obando, S. (2015) Serjania. In: Bernal, R., Gradstein, S.R. \& Celis, M. (Eds.), Catálogo de plantas y líquenes de Colombia. Instituto de Ciencias Naturales, Universidad Nacional de Colombia, Bogotá. Available from: http://catalogoplantasdecolombia.unal.edu.co (accessed 7 June 2021)

Pereira, H., Belnap, J., Brummitt, N., Collen, N., Ding, H., Gonzales-Espinosa, M., Gregory, R., Honrado, J., Jongman, R.H.G., Julliard, R., McRae, L., Proença, V., Rodrigues, P., Opige, M., Rodríguez, J., Schmeller, D.S., van Swaay, C. \& Vieira, C. (2010) Global Biodiversity Monitoring. Frontiers in Ecology and the Environment, 8 (9), 459-460. https://doi.org/10.1890/10.WB.23

Porter, D.M. \& Sytsma, K.J. (2019) Sapindales. Encyclopedia Britannica, 10 Jan. 2019, https://www.britannica.com/plant/Sapindales (accessed 10 June 2021)

Puplesis, R. (2002) Biodiversity: an introduction to global animal and plant diversity. Lutute Publishers, Kaunas, 154 pp. [in Lithuanian]

Robinson, G.S., Ackery, P.R., Kitching, I.J., Beccaloni, G.W. \& Hernández, L.M. (2010) HOSTS—A Database of the World's Lepidopteran Hostplants. Natural History Museum, London. Available from: http://www.nhm.ac.uk/hosts (accessed 18 December 2020)

Puplesis, R. \& Diškus, A. (2003) The Nepticuloidea \& Tischerioidea (Lepidoptera) - a global review, with strategic regional revisions. Monograph. Lutute Publishers, Kaunas, 512 pp.

Sánchez-Bayo, F. \& Wyckhuys, K.A.G. (2019) Worldwide decline of the entomofauna: A review of its drivers. Biological Conservation, 232, 8-27. https://doi.org/10.1016/j.biocon.2019.01.020

Schmeller, D., Böhm, M., Arvanitidis, C., Barber-Meyer, S., Brummitt, N., Chandler, M., Chatzinikolaou, E., Costello, M., Ding, H., Garcia Moreno, J., Gill, M., Haase, P., Jones, M., Juillard, R., Magnusson, W., Martin, C., McGeoch, M., Mihoub, J.-B., Pettorelli, N. \& Belnap, J. (2017) Building capacity in biodiversity monitoring at the global scale. Biodiversity and Conservation, 26, 2765-2790. https://doi.org/10.1007/s10531-017-1388-7

Schnitzer, S.A. \& van der Heijden, G.M.F. (2019) Lianes have a seasonal growth advantage over co-occurring trees. Ecology, 100 (5), e02655. https://doi.org/10.1002/ecy.2655

Sharkey, M.J., Janzen, D.H., Hallwachs, W., Chapman, E.G., Smith, M.A., Dapkey, T., Brown, A., Ratnasingham, S., Naik, S., Manjunath, R., Perez, K., Milton, M., Hebert, P., Shaw, S.R., Kittel, R.N., Solis, M.A., Metz, M.A., Goldstein, P.Z., Brown, J.W., Quicke, D.L.J., van Achterberg, C., Brown, B.V. \& Burns, J.M. (2021) Minimalist revision and description of 403 new species in 11 subfamilies of Costa Rican braconid parasitoid wasps, including host records for 219 species. ZooKeys, 1013, 1-665. https://doi.org/10.3897/zookeys.1013.55600

Sinev, S.Yu. (Ed.) (2019) Catalogue of the Lepidoptera of Russia. Edition 2. Zoological Institute RAS, St. Petersburg, 448 pp. [in Russian]

Stevens, P.F. (2017) Angiosperm Phylogeny Website. Available from: http://www.mobot.org/MOBOT/research/APweb/ (accessed 7 June 2021)

Stonis, J.R. \& Diškus, A. (2008) Checklist of American Coptotriche (Insecta: Lepidoptera: Tischeriidae) with descriptions of two new species from the tropical forest of Belize (Central America). Zoological Science, 25 (1), 99-106. https://doi.org/10.2108/zsj.25.99

Stonis, J.R., Diškus, A., Carvalho Filho, F. \& Lewis, O.T. (2018) American Asteraceae-feeding Astrotischeria species with a highly modified, three-lobed valva in the male genitalia (Lepidoptera, Tischeriidae). Zootaxa, 4469 (1), 1-69. https://doi.org/10.11646/zootaxa.4469.1.1

Stonis, J.R., Diškus, A., Paulavičiūte, B. \& Monro, A.K. (2017) Urticaceae-feeders from the family Tischeriidae: descriptions of two new species and new genus Paratischeria gen. nov. Biologija, 63 (1), 1-22. https://doi.org/10.6001/biologija.v63i1.3470

Stonis, J.R., Diškus, A., Remeikis, A., Katinas, L., Cumbicus Torres, N., Schuster, J. \& Puplesyte-Chambers, J. (2019a) Diagnostics of new species of Neotropical Tischeriidae (Lepidoptera), with the first record of Coptotriche Walshingham from South America. Zootaxa, 4691 (1), 1-32. https://doi.org/10.11646/zootaxa.4691.1.1

Stonis, J.R., Diškus, A., Remeikis, A. \& Lewis, O.T. (2020a) Exceptional diversity of Tischeriidae (Lepidoptera) from a single tropical forest site in Belize, Central America. European Journal of Taxonomy, 723, 33-76. https://doi.org/10.5852/ejt.2020.723.1143

Stonis, J.R., Diškus, A., Remeikis, A. \& Navickaite, A. (2014) Study methods of Nepticulidae: micro-mounts of genitalia structures. In: Stonis, J.R., Hill, S.R., Diškus, A. \& Auškalnis, T. (Eds.), Selected abstracts and papers of the First Baltic International Conference on Field Entomology and Faunistics. Edukologija Publishers, Vilnius, pp. 32-35.

Stonis, J.R., Diškus, A., Remeikis, A., Solis, M.A. \& Katinas, L. (2020b) Exotic-looking Neotropical Tischeriidae (Lepidoptera) and their host plants. ZooKeys, 970, 117-158. https://doi.org/10.3897/zookeys.970.54801 
Stonis, J.R., Diškus, A., Solis, M.A. \& Monro, A.K. (2021) Diagnostics of Manitischeria gen. nov., an Old-World genus of leafmining Tischeriidae, composed of new species and species formerly in Tischeria Zeller. Zootaxa, 4964 (2), 251-287. https://doi.org/10.11646/zootaxa.4964.2.2

Stonis, J.R., Remeikis, A., Diškus, A., Davis, D.R. \& Solis, M.A. (2020c) American Tischeriidae (Lepidoptera) from the collection of the National Museum of Natural History, Washington D.C. Proceedings of the Entomological Society of Washington, 122 (2), 482-505.

https://doi.org/10.4289/0013-8797.122.2.482

Stonis, J.R., Remeikis, A., Vargas, S. (2019b) Colombian Nepticuloidea and Tischerioidea: a small step out of obscurity? Biologija, 65 (2), 48-55. https://doi.org/10.6001/biologija.v65i2.4023

Stonis, J.R. \& Solis, M.A. (2020) Dishkeya gen. nov., a New World endemic genus of leaf-mining Tischeriidae (Lepidoptera), transferred from Tischeria Zeller. Biologija, 66 (3), 123-135. https://doi.org/10.6001/biologija.v66i3.4307

Thiers, B. (2021) Index Herbariorum: A global directory of public herbaria and associated staff. New York Botanical Garden's Virtual Herbarium. Available from: http://sweetgum.nybg.org/ih/ (accessed 8 June 2021)

Vane-Wright, R.I. (1992) Systematics and global biodiversity strategy. Antenna, 16, 49-56.

Vane-Wright, R.I. (1996) Systematics and the Conservation of Biological Diversity. Annals of the Missouri Botanical Garden, $83(1), 47-57$. https://doi.org/10.2307/2399967

Weckerle, C.S. \& Rutishauser, R. (2005) Gynoecium, fruit and seed structure of Paullinieae (Sapindaceae). Botanical Journal of the Linnean Society, 147 (2), 159-189. https://doi.org/10.1111/j.1095-8339.2005.00365.x

Xu, J., Dai, X., Liao, C., Diškus, A. \& Stonis, J.R. (2018) Discovery of Ulmaceae-feeding Tischeriidae (Lepidoptera, Tischerioidea), Tischeria ulmella sp. nov., and the first report of the Quercus-feeding T. naraensis Sato in China. Zootaxa, 4399 (3), 361-370. https://doi.org/10.11646/zootaxa.4399.3.6

Xu, J., Dai, X., Liu, P., Bai, H., Diškus, A. \& Stonis, J.R. (2017) First report on Paratischeria from Asia (Lepidoptera: Tischeriidae). Zootaxa, 4350 (2), 331-344. https://doi.org/10.11646/zootaxa.4350.2.8

Zattara, E. \& Aizen, M. (2021) Worldwide occurrence records suggest a global decline in bee species richness. One Earth, 4 (1), 114-123. https://doi.org/10.1016/j.oneear.2020.12.005

Zhang, Z.-Q. (2008) Accelerating biodiversity descriptions and transforming taxonomic publishing: The first decade of Zootaxa. Zootaxa, 2896 (1), 1-7. https://doi.org/10.11646/zootaxa.2896.1.1

Zhang, Z.-Q. (2011) Describing unexplored biodiversity: Zootaxa in the International Year of Biodiversity. Zootaxa, 2768 (1), 1-4. https://doi.org/10.11646/zootaxa.2768.1.1 